\title{
Revealing Whiteness in Preservice Music Teacher Preparation
}

\author{
Andrea VanDeusen \\ East Carolina University
}

Educational institutions and teacher education preparation programs tend to reflect White Eurocentric beliefs and values. Additionally, White preservice teachers may have little understanding of their own cultural backgrounds, as they are largely unexamined in a structure of White norms. In this paper, I draw upon elements of critical whiteness studies as a framework to further analyze data from a prior, larger study about an immersion field experience to reveal the ways in which whiteness was largely unacknowledged but always lurking in the background of the experience-in participants' discourses about their experiences and interactions with students of color in the music classrooms. This deepened understanding of whiteness embedded in the experience was imperative for considering how to better facilitate field experiences for White preservice music teachers and how to better prepare them to work successfully with students of color.

Keywords: Whiteness, critical whiteness studies, music teacher preparation, music education

hough student demographic trends reflect the growing racial, cultural, and
ethnic diversity in the United States, the teaching population has remained
relatively unchanged: White, female, middle-class, and monolingual (National Center for Education Statistics 2019, 2020; Picower 2009). Educational institutions and teacher education preparation programs also tend to reflect monocultural, White Eurocentric beliefs and values (Ladson-Billings 2009, Picower 2009). As a result, White preservice teachers may have little understanding of their own cultural backgrounds, as they are largely unexamined in a structure informed by White norms. They also may have little understanding of race and their own positionalities in teaching and learning. As Ladson-Billings (2001) asserted, "Notions of Whiteness are taken for granted. They rarely are interrogated. But being White is not merely about biology. It is about choosing a system of privilege and power" (81).

(C) Andrea VanDeusen. The content of this article is the sole responsibility of the author. The ACT Journal and the Mayday Group are not liable for any legal actions that may arise involving the article's content, including, but not limited to, copyright infringement. 
Teacher educators recognize the importance of better preparing White preservice teachers by facilitating opportunities to build cultural competence and sociocultural understanding. Yet many White preservice and in-service teachers report feeling unprepared to teach students whose racial identities differ from their own, having often only engaged in practicum settings that resemble their own racial, ethnic, and cultural backgrounds (Bradfield-Kreider 2001, Kelly 2003, Picower 2009, Sleeter 2001). Some studies suggest that practicum field experiences with a community immersion component can help White preservice teachers develop a deeper understanding of racial and cultural differences and their impacts on teaching and learning (Irvine 2003). Immersion experiences can provide opportunities for White preservice teachers to begin dismantling previously held stereotypes and perceptions and can help reduce fears they may have regarding working with students of color (Sleeter 2001). However, immersion field experiences also have the potential to reinforce White preservice teachers' implicit biases and stereotyped perceptions of people of color (Cockrell, Placier, Cockrell, and Middleton 1999; del Prado Hill, Friedland, and Phelps 2012). White preservice teachers can approach field experiences in communities of color with "apprehension, missionary zeal, and culture blindness" (del Prado et al. 2012, 83) and project deficit views on students and the community (Ladson-Billings 2009, Matias 2015). Though diversity courses in teacher education may address whiteness and white privilege, White preservice teachers' conceptual understanding of their privilege does not always help them understand structural privileges, and they may be defensive about white supremacy as they simultaneously reduce students of color to a stereotyped collective (Vaught and Castagno 2008).

Some music teacher educators recognize that music education is steeped in White supremacy (Bradley 2007, Hess 2017, Koza 2008). White supremacy may be reflected in student access to and participation in school music. School music programs vary among communities, and those without music course offerings are more likely to serve students of color than their White counterparts (Salvador and Allegood 2014). Yet access to school music programs may not be the only issue related to school music participation. In a study of high school ensemble music course participants, Elpus and Abril (2019) found that White, middle class students were more likely to participate in ensemble music classes than students of color or students from low socioeconomic backgrounds. This may be further complicated by music curricula and pedagogies in school music and music teacher preparation. Traditional music curricula and its focus on the Western art canon, as 
well as the myth of music as a universal language, uphold White supremacy and reinforce racism by "othering" all that falls outside of its paradigm (Bradley 2006, Hess 2017, Koza 2008, Vaugeois 2007). Bradley (2006) asserted that because of music education's tendency to cater to whiteness, music teachers and music teacher educators can hide in a "luxury of ignorance" with their predominately White student enrollment, not needing to know about or interact with students of color (195). Music teacher educators may perpetuate this "luxury" by focusing on teaching music methods at the expense of guiding preservice music teachers toward understanding students' racial identities and experiences (Salvador and Kelly-McHale 2017). Some music teacher educators recognize this notion and seek to facilitate field experiences in culturally different settings to better prepare preservice teachers (Kelly 2003, McKoy 2013). Yet because music programs are more likely to be comprised of White students, it may be difficult for music teacher educators to provide field experiences in demographically varied school music settings. When such field experiences do occur, they may not necessarily have long term impacts on preservice music teachers' cultural competence or prompt them to consider future teaching settings with students who do not share their racial backgrounds (Kelly 2003, McKoy 2013). White music teachers and music teacher educators also may not have had experiences in which they examine their implicit biases and critically reflect on their positionalities, particularly as they relate to students of color in their classrooms.

\section{Context}

In a larger research project (VanDeusen 2019), I explored preservice music teachers' beliefs, assumptions, and understandings about music teaching and learning with students whose cultural backgrounds differed from their own. I facilitated a cultural immersion field experience in which preservice music teachers engaged in music teaching and learning with elementary students and their music teachers in public schools in a predominately Arab and Muslim community. The study was an instrumental case study (Stake 1995) comprised of three components: 1) pre-immersion meetings with readings and guided discussions about sociocultural issues in schools and society, as well as information specific to the community of the field experience; 2) a week-long immersion field experience in which participants engaged in both observations and music teaching alongside the music teachers in the classrooms and experienced the community outside of the school day through 
guided and self-guided visits to the community museum, restaurants and shops; and 3) post-immersion follow up meetings to explore the impact of the experience for participants. Participants were nine undergraduate music education students who volunteered to participate in the study and in the immersion field experience. All were White, from the Midwest, identified as Christian or Jewish, and were from racially and culturally homogenous communities, having had few experiences with individuals from racial, ethnic, or cultural groups outside their own. ${ }^{1}$ My role as a researcher was participant-observer, and I shared the experience with participants (Creswell 2013). Research questions from the larger study focused originally on participants' perceptions of their experiences in the music classrooms. Questions did not focus on critical examinations of race or racialized identities. Data were collected in each component through individual and group interviews and discussions, journals, and observations.

One day near the end of the immersion week, schools closed due to inclement weather the night before. Participants and I used the unexpected free time to further explore the neighborhood that housed the schools. We entered this exploration with no agenda, no plan for places to visit and no predetermined length of time or determination for how the group would explore among and within itself. The stores were mid-sized, and participants traveled in a group, sometimes splitting into smaller groups of 3 or 4 . Some purchased items while others did not. Despite having visited local shops after school ended each day throughout the week without expressing fear, the experiences on this particular day revealed that participants experienced racial discomfort being in the community. Some participants perceived shoppers and store workers staring at them. Others perceived that the shoppers and store workers were not particularly interested in our presence. Yet some participants displayed uneasiness in stores and expressed this during a group discussion later that evening. They shared feelings like, "we should not have been in the community," "people stared at us like we did not belong," and "we did not belong in those spaces." It was clear that they perceived themselves as racial and cultural outsiders. This perspective had not previously emerged in group discussion and differed from what they shared about their experiences at the school. As participants discussed their feelings, they began to connect their experiences in the community to their experiences at school. In a group discussion, Alexis shared that she had not thought consciously about her racial identity nor had she recognized that she was a racial minority in the school. She said, "Maybe it's just because I'm

VanDuesen, Andrea. Revealing whiteness in preservice music teacher education. Action, Criticism, and Theory for Music Education 20 (1): 121-41. https://doi.org/10.22176/act20.1.121 
not used to being the minority that it just doesn't occur to me, but I feel like I just haven't really been thinking about that in the schools at all" (group discussion).

Alexis' words continued to resonate with me after the original study concluded. While participants had been guided to consider the racial dynamics present in the music classrooms they observed, they had not been compelled to critically examine their own racial identities until their time in the community. This revelation prompted me to further examine how participants perceived their experiences in the community, their experiences in the music classroom, and their understanding of race and of whiteness. Using critical whiteness studies as a framework, this reexamination of the data seeks to reveal the ways in which whiteness was enacted in participants' discourses about their experiences in the community and with students of color in the music classroom. I analyzed data by employing values coding, emotion coding, and focused coding (Saldaña 2013) to make meaning of the findings. I then organized data into themes through which to name elements of critical whiteness. I asked the following questions: How is whiteness reflected in participants' descriptions and perceptions of their experiences in the community and the music classrooms? How does whiteness inform participants' reactions to their experiences?

\section{Positionality}

It is important to be clear: this investigation is not about the experience in and of itself. Rather, the event I describe, and the ensuing discussions, served as a catalyst for a re-examination of the data to gain new and deeper insights into the racial dynamics present in the experience at the core of the larger study, in participants' perceptions of their experiences, and in my analysis of their perceptions. In the larger research study, I sought to facilitate a field experience that would prompt participants to think critically about culture and cultural difference in music teaching and learning. In that pursuit, I facilitated engagements in the community that I believed would help them contextualize their experience and potentially dismantle stereotypes they may have held. What I did not fully understand at the time were the racial and social power structures that inherently advantaged me and my participants despite our outsider status in the community. My assumption that the group had open access to spaces in the community was an enactment of whiteness in my work. This assumption reflects aspects of cultural voyeurism by positioning the community and its members as objects of fascination (Hart and Montague

VanDuesen, Andrea. Revealing whiteness in preservice music teacher education. Action, Criticism, and Theory for Music Education 20 (1): 121-41. https://doi.org/10.22176/act20.1.121 
2016). Though my intent was for participants to learn by spending time in the community, curiosity is "innocuous until placed in the wider context of power relations" (Hart and Montague 2016, 7). I continue to reflect on these experiences and acknowledge that one must more critically consider community engagements, particularly when those communities are comprised of people who are marginalized by societal structures of power.

In sharing my findings, I also recognize that my ongoing understanding of and entangled relationship with whiteness is embedded in my analysis (Cabrera, Watson, and Franklin 2016). My identity as a White researcher and as a White participant-observer in the study who facilitated the experience and built relationships with each White participant impacted my work. I frequently experienced dissonance critiquing participants' and my perceptions and behaviors and having compassion for us as we navigated and interpreted our experiences. This is a reflection of my own relationship and complicity with whiteness as a White person (Cabrera et al. 2016). With that in mind, I offer my interpretation of nine White participants' enactments of whiteness and perceptions of race and racial spaces during an immersive field experience in the community and music classrooms.

\section{Theoretical Framework}

In this investigation, I draw upon elements of critical whiteness studies (BonillaSilva 2013, DiAngelo 2011, Harris 1993, 1995, Matias 2016) to examine the ways in which whiteness informed participants' perceptions of and discourse about their experiences. Critical whiteness studies assert that "whiteness is the underlying mechanism that maintains a racist system, and not acknowledging whiteness contributes to the permanence of race and racism" (Matias, Viesca, Garrison-Wade, Tandon, and Galindo 2014). Whiteness' power comes from its invisibility (Rodriguez 2000). DiAngelo (2011) defined whiteness studies as a lens that begins "with the premise that racism and white privilege exist in both traditional and modern forms, and rather than work to prove its existence, work to reveal it" (56). Nishi, Matias, Montoya, and Sarcedo (2016) described whiteness as an ideology that works to normalize and promote white supremacy (2). It operates by centralizing white culture, history, language, beauty standards, and traditions as normal, thereby "othering" that which is outside of it (Leonardo 2004; Harris 1993, 1995; Picower 2009). Because we live in a dominant culture of whiteness in the United States, whiteness can be internalized by, and often invisible to, both White people

VanDuesen, Andrea. Revealing whiteness in preservice music teacher education. Action, Criticism, and Theory for Music Education 20 (1): 121-41. https://doi.org/10.22176/act20.1.121 
and people of color. Thus, it is important to reveal its presence and its workings for all to better identify and understand.

White people can perform whiteness in many ways. One performative tool of whiteness occurs when White people seek to help people of color because they view them as poor and needy. Rather than learning how to address racism, White people can reaffirm their own identities as "good people" while simultaneously reinforcing racism by imposing themselves on communities that "need" their help (Picower 2009). For this investigation, I draw on four aspects of whiteness: whiteness as property (Harris 1995), white fragility (DiAngelo 2011), white emotionality (Matias 2016), and colorblind racism (Bonilla-Silva 2013).

Harris (1993) described whiteness as property as "the legitimation of expectations of power and control that enshrine the status quo as a neutral baseline, while masking the maintenance of white privilege and domination" (1715). Whiteness as property elevates and prioritizes white cultural norms. It manifests as civil rights and liberties, societal powers, immunities, and privileges gained simply by being part of the dominant power group. It also "others" those outside of the power group.

DiAngelo (2011) defined white fragility as "a state in which even a minimal amount of racial stress becomes intolerable, triggering a range of defensive moves," including "the outward display of emotions such as anger, fear, and guilt, and behaviors such as argumentation, silence, and leaving the stress-inducing situation" (54). It also manifests as anxiety in situations where one is the only White person in a space or in fears of being singled out for being White (Bonilla-Silva 2013, Picower 2009). Evidence of white fragility becomes apparent when White people feel discomfort, become defensive, explain away, or withdraw from and thereby shut down conversations about race and racism to protect their own feelings and comfort (DiAngelo 2011).

White emotionality (Matias 2016) describes the defensiveness a White person might express to make sense of their white fragility. White people feel shame about their complicity in individual and/or systemic racism and are "so invested in their Whiteness that they superiorize their discomfort above the daily discomfort people of color experience" (Matias 2016, 18-19). Defensiveness may manifest as guilt, anger, denial, and tension when discussing race. White emotionality comes with the tendency to blame others, rather than making sense of systemic issues in which all White people participate.

VanDuesen, Andrea. Revealing whiteness in preservice music teacher education. Action, Criticism, and Theory for Music Education 20 (1): 121-41. https://doi.org/10.22176/act20.1.121 
Bonilla-Silva (2013) defined colorblind racism as a way for White people to explain away racism as a cause for inequities. Colorblind racism might include using coded language surrounding race to minimize fear or discomfort (Bradley 2006, Hess 2017). Bonilla-Silva (2013) identified four frames of colorblind racism: abstract liberalism, naturalization, cultural racism, and minimization of racism. Three of these frames were particularly relevant to this investigation. Cultural racism "relies on culturally based arguments such as 'Mexicans do not put much emphasis on education' or 'blacks have too many babies' to explain the standing of minorities in society" (Bonilla-Silva 2013, 76). It denies racial inequities and instead explains minorities' standings in society as a result of lack of effort or hard work rather than acknowledging the impact of systems of power on individuals and marginalized groups. Cultural racism is used to defend and justify the societal status quo by projecting cultural deficits on racial minorities. In so doing, White people are able to distance themselves from both systemic and individual racism (Bradley 2015). Naturalization of personal preferences posits that segregation into like groups is a part of a normal social process and not a form of discrimination. One example of naturalization is the argument that White people choose to live in neighborhoods with other White people and Black people choose to live in neighborhoods with other Black people, ignoring the impacts of redlining and other housing policies that contribute to neighborhood segregation. The argument removes racism as a component of neighborhood segregation and places onus on personal preferences instead. Minimization of racism assumes that racial discrimination no longer exists but rather is used as an excuse by people of color to explain inequities. Minimization of racism removes race from the cause of racist interactions or decisions and projects it on to something else, placing blame and responsibility on marginalized individuals rather than on systems of power.

As noted previously, I draw upon these elements of critical whiteness studies as a framework for further analysis of data from the larger study, to reveal the ways in which whiteness was largely unacknowledged but always lurking in the background of the experience. This understanding was imperative in order to determine how to better prepare these participants and other White preservice music teachers to work successfully with students of color and to teach using antiracist pedagogies.

VanDuesen, Andrea. Revealing whiteness in preservice music teacher education. Action, Criticism, and Theory for Music Education 20 (1): 121-41. https://doi.org/10.22176/act20.1.121 


\section{Findings and Discussion}

In my findings, I focus on the revelation of participants' fear and discomfort in the local community and the extended impact of their experience on participants' perceptions of their work in music classrooms. Despite engaging primarily with students of color in the music classrooms, participants first verbalized that they were racial minorities during their experience in the community. I organized participants' perceptions into four categories: discomfort, perspective taking, white savior, and reconsidering racial dynamics in the music classrooms. Next, I identified the ways in which whiteness was present in their perceptions and understandings of their experiences. I combined the Findings and Discussion sections purposefully, so that participants' enactments of whiteness and privilege could be examined alongside the findings rather than removed to a separate discussion.

\section{Discomfort}

During their immersion in the local community, participants experienced varying degrees of personal discomfort surrounding their White identity, which they expressed through feelings of distress, fear, and anger toward me as the group leader for taking them to local stores. Jane shared how she felt about visiting a local grocery store:

The whole experience made me feel pretty uncomfortable. I felt like we were sort of intruding on their cultural spaces. I could understand why they were gawking at us and making faces, since we were sort of placing ourselves where we didn't necessarily fit or belong at all... They seemed a little suspicious of us and kept staring. I don't blame them. The women were especially staring at us, perhaps because of how we dressed more liberally than they were, in terms of what we had covered up... I feel bad that we invaded their cultural space. (journal entry)

Jane's journal entry revealed the self-consciousness that she and others felt in the community as a racial and cultural minority. Her feelings displayed markers of white fragility (DiAngelo 2011), as the stress of being White in the store manifested as apprehension about how people perceived her, particularly in relation to Jane's expectations about female dress in Muslim culture. She also displayed white emotionality (Matias 2016) in her fear that people were staring at her, her guilt that they did not want her in the store, and shame that she did not belong.

On the other hand, Alexis questioned her reaction to the experience:

I felt weird. I was not very comfortable. But if the situation were not with groups of Arab people, would it have mattered? When I was in Germany, we would go in 
stores and it wasn't weird at all. So, I guess I'm thinking, why is that weird? I don't know. I think it's a subconscious thing or through the media or whatever that there's such a perceived --like, it has to be weird because it's these two groups of people. I'm trying to word this in a way that doesn't make me seem racist, but I feel like if it weren't in an Arab store, we wouldn't have felt so weird if it were White culture. (group discussion)

Alexis acknowledged that her experiences in Germany differed from her experience in the community. She recognized that there was a racial as well as sociopolitical component to her discomfort. She also illuminated an interesting perspective of national identity. Though immigrants and refugees continue to relocate to the area, Alexis was in a well-established community in the United States. Many of the stores and restaurants had existed for generations and were likely owned by American citizens. Yet, Alexis compared her experience in a community in the United States to an experience she had in Germany, linking her anxiety to the absence of "white culture" and perceived national identity. Her perspective raises the question of what and who is American. Is the collective default American culture "white culture" (Bradley 2009)? And if so, what implications does this perception carry for people of color who are American citizens?

\section{Perspective Taking}

Some participants thought about their discomfort in the community and related it to experiences of people from racially, culturally, and linguistically marginalized groups in the United States. Signs and labels in the neighborhoods and stores were in Arabic, so participants were not always able to discern items they perused. George shared his frustration when he was unable to read labels in the stores and thought about how difficult that would be to encounter on a regular basis.

I got really frustrated when there was a food and it was all in Arabic... I saw a bunch of stuff that looked kind of cool. I was like, oh, I wonder what this is. I have no idea because it's in a language I don't understand. That was frustrating for me and I thought, Wow. If that was mildly frustrating for me, what if I was on the flip side and I spoke Arabic and I was surrounded by things in English? (group discussion)

George's frustration suggests he felt a loss of whiteness as property (Harris 1993) as he felt unable to use language in the space. Perhaps, at least to some degree, George recognized the privilege associated with speaking English in schools and society and was able to take the perspective of those for whom English was not the primary language. 
Sierra also felt uncomfortable in the local stores, which helped him consider how persons from marginalized groups may feel in communities throughout the United States:

Walking around the grocery store was an interesting experience. This was one of the first times in my life where I was in the racial minority. I felt as though people were looking at me, wondering why I was there. Nobody seemed angry, just curious. I couldn't help but think about how it feels to be Arab in this country. Something as harmless as getting looked at made me feel so uncomfortable. If this was just one time for me, I can't imagine how uncomfortable these people must feel on a daily basis. I almost felt like I needed to explain to everyone why I was there and that I was not a bad person. This feeling must occur to Muslims every day in America. (journal entry)

Sierra acknowledged that he had not previously experienced being one of few White people in a space. He felt uncomfortable as people looked at him, and he feared that they questioned his presence in the store. His discomfort is a reflection of white fragility (DiAngelo 2011). Sierra also appeared to conflate Arab and Muslim identities. Though people in the community likely comprised both identities, it was unclear whether Sierra understood the distinction. Finally, though Sierra and other participants may have felt uncomfortable and even unwelcome in the community, they were White in the United States. They may have felt uncomfortable, but they still maintained power, even in a space comprised predominantly of people of color (Nishi et al. 2016).

\section{White Savior}

At the end of the week, participants and I engaged in a final group discussion to debrief about the final day at the schools and the week that preceded it. Participants were emotional about leaving students and teachers with whom they had developed relationships, and they grappled with sociocultural and political issues that emerged from their experiences. During the discussion, some participants revealed their expectations coming into the experience. In a conversation about what most resonated with participants, Luke shared:

Are we doing enough? What can we do-not that we need to save anybody or ... do anything like that, but ... asking to help is different than ... forcing yourself on other people. And forcing them to adapt to your culture or your way of life. (group discussion)

Luke seemed to understand from a philosophical perspective that he didn't need to "save" anyone. Yet he also felt compelled to help from his privileged 
position. Participants discussed their perceptions and expectations of the community and the students amidst current sociopolitical events surrounding Arab, Muslim, immigrant, and refugee populations. Simon offered:

I think, to some degree, I expected to show up like, here come the White people to save the day. Not to a crazy amount, but I think I was mildly surprised to see that wasn't the case. I guess on one hand, I was like: It will be a normal classroom. It's not going to be that different, but on the other hand, I figured-just from all you hear in the media and how their culture is being persecuted, that you would see more of that-children feeling less joy and happiness and normalcy... Maybe I had that expectation because-why would we be going and doing this big trip if it weren't for some type of noble cause? (group discussion)

Simon's comment revealed a number of assumptions. First, he perceived Arabs, Muslims, immigrants, and refugees as persecuted, traumatized people whose prior traumatic experiences would manifest in the classrooms. He was surprised to find students who were happy and resembled students with whom he interacted in other settings. Second, though some students were recent immigrants and refugees from war-torn countries, others were American citizens whose families had lived in the community for generations. Yet, Simon seemed to perceive their identities and experiences as a monolithic group rather than as individuals.

Additionally, Simon's comment raises the question of "normal classrooms." What is a normal classroom and from whose perspective? Simon may have perceived "normal classrooms" as those that resembled his experiences as a student. His perception also may have reflected the school contexts he came to expect in his field experiences as part of music teacher preparation. Many of his prior field experiences occurred in school music programs with predominately White and middle-class student populations, and he may have perceived the few that took place in schools with large populations of students of color as token experiences. This context abnormality may have impacted Simon's expectation that his experience was part of a "noble cause," which suggests that he may have believed that he might help students in the community who were less fortunate than he. His assumptions reflect whiteness as an ideology: he viewed white culture and traditions as "normal" and projected deficit on students of color and their community (Harris 1995, Leonardo 2004, Nishi et al. 2016, Picower 2009). These assumptions likely were enhanced by stories he had heard about refugee students' past experiences. Their traumatic experiences became central to Simon's perception of their identity, allowing him, and perhaps others, to assume students of color needed help, while

VanDuesen, Andrea. Revealing whiteness in preservice music teacher education. Action, Criticism, and Theory for Music Education 20 (1): 121-41. https://doi.org/10.22176/act20.1.121 
simultaneously feeling good about participating in a "noble cause" (Leonardo 2004, Nishi et al. 2016, Picower 2009).

\section{Reconsidering Racial Dynamics in the Music Classrooms}

Participants reflected on their experiences in the community and the ways in which fluency in society's dominant language benefitted their lived experiences. They also began to connect their experiences in the community to music classroom environments.

Alexis: I feel like if one of the people in the Arab community says something to me and I don't understand it... I feel like I don't want to say that I didn't understand what they said the first time because I feel ... not racist, but weird.

George: The same thing happened at school. I asked a kid what his name was. He said his name quietly and it was an Arabic name. I didn't quite catch it, and rather than asking again what he said, I was like, I'll just fake it and sit here.

Alexis: Yeah, I just won’t ever say his name.

George: In that moment, I was like, Oh my gosh! What's happening to me right now? (group discussion)

Alexis and George recognized their privilege as English speakers and admitted that they used their privilege to avoid learning or asking for clarification of students' names in the classroom. They even seemed to understand the racist undertones of their behavior. Alexis and George enacted whiteness as property (Harris 1993), as they were able to maintain the systemic power dynamic despite not being able to speak Arabic. They also normalized "white" names and did not prioritize learning and knowing students' names, particularly when it was difficult for them.

Another enactment of whiteness as property (Harris 1993) occurred when Lisa reflected on compliments she received from students about her appearance.

A couple of girls started to touch my hair and say how beautiful it was. Maybe I wasn't thinking, but I couldn't figure out why... For most of my life, being White and having blond hair is the basic way to be. Looking back on it, there is no reason I should have been confused about why they seemed to like it so much... Race isn't something I think about ... my blond hair is just not something I think about. (journal entry)

Lisa assumed that students admired her blond hair because it reflected standards of white beauty (Taylor 1999). She enjoyed the privilege of not having to 
consider her racial identity as she navigated her world. These types of standards reinforce white supremacy (Harris 1995).

White supremacy centralizes whiteness as "normal" (Harris 1993, Leonardo 2004), and privileges White people with the ability to largely ignore race as part of their identity. It also might prevent them from fully understanding how racial identities impact the lived experiences of people of color. Alexis revealed this normalization when she admitted that she had not thought about her racial identity in the music classrooms or considered the dynamics of being White in a classroom comprised predominately of students of color. Yet in the community, being White and a racial minority permeated her thoughts. Her self-consciousness from feeling "watched" prompted a visceral emotional reaction for her and other participants. She reflected in a journal entry:

Honestly, maybe they weren't even staring at us the way I thought they were, and I was just really self-conscious being there. I think that the stores were the only time this week that I have been very conscious of being White and that maybe people don't think I belong. At the school, I didn't even think about the fact that we were some of the only White people there. (journal entry)

The schools were comprised predominantly of students of color. Participants engaged with students of color every time they were in a music classroom. Yet, they did not express any apprehension as racial minorities until they were in the community. Why did participants feel comfortable in the schools and not in local stores? Why was their White identity pervasive to their thoughts in the community and absent in the music classrooms? Though the teachers represented many racial and cultural identities, some were White and shared cultural backgrounds similar to the participants. Did this provide participants with a perception of belonging in the schools that differed from the community? What are the implications for students of color if their White teachers do not consider race in schools and in their classrooms?

\section{Implications and Conclusions}

The revelation that participants did not think about race in the music classrooms when it permeated their experience in the community resonated strongly with me as a White researcher and music teacher educator. It also prompted me to reflect critically on my own experience. What privileges do I hold as a White woman engaging with people in a community of color; in a school comprised primarily of students of color? What must I understand about race, racial dynamics, and my 
entanglement with my White identity in order to best facilitate music teaching and learning experiences for my students? Particularly amidst predictions of growing numbers of students of color (National Center for Education Statistics 2019) and relatively stagnant numbers of White in-service teachers (National Center for Education Statistics 2020), White teachers' inability to understand the impact of race in schools and music classrooms may further exacerbate racial inequities for their students. This suggests implications for field experiences in music teacher preparation, particularly for White preservice music teachers. Participants' experiences in the local community differed from their experiences in the schools and served as a catalyst for discussing White identities that may not otherwise have occurred. This finding aligns with extant literature that suggests community engagement is an important component of field experiences to help preservice teachers understand schools and local contexts (Bradfield-Kreider 2001).

The experience also highlights the complications inherent in facilitating field experiences for preservice teachers. In any field experience, preservice music teachers practice their beginning teaching skills and learn through trial-and-error experiences. They are, in essence, experimenting on other people's children (Cross, Tosmur-Bayazit, and Dunn 2018). This reality is complicated when White music teacher educators partner with White music teachers to facilitate experiences for White preservice music teachers in schools where the student body is comprised primarily of students of color. Without thinking critically about these dynamics, music teacher educators, music teachers, and preservice music teachers may reinforce aspects of whiteness as property (Harris 1995) by privileging their embedded positions of power as White teachers, prioritizing White cultural norms in social and behavioral interactions, teaching pedagogies, and music content. As facilitators of field experiences, music teacher educators must consider how best to guide preservice music teachers' development without ignoring societal power imbalances and further exploiting students of color in the classes they teach (Cross, Tosmur-Bayazit, and Dunn 2018).

Music teacher educators also might more deeply consider connections between field experiences, content covered, and experiences provided in preservice music teacher preparation coursework. In this investigation, participants' conceptual understandings of racial, cultural, and ethnic inequities and social justice conflicted with their perceptions and feelings in the local community and in the classrooms. Music teacher educators might consider exploring ways to ethically facilitate opportunities for preservice music teachers to experience discomfort and 
dissonance while providing guidance for reflecting upon and unpacking their perceptions and understandings of their experiences, both in music classrooms and in engagements with the local community. They might consider how to continue to reveal and examine whiteness in society, schools, curricula, coursework, field experiences, and music teacher identity development for themselves and alongside preservice music teachers. Without this preparation, music teacher educators risk sending preservice music teachers into the field with implicit or explicit endorsements of white supremacy (in society and music education), as biases may be reinforced if they are not addressed. Preservice music teachers must enter the profession with both a conceptual understanding of white supremacy and practical implications for anti-racist teaching practices in order to dismantle the whiteness embedded in music teaching and learning (Crowley 2016).

To reach these aims, it will be important for music teacher educators to continue to examine and unpack their own racial identities and complicity with whiteness in order to facilitate discussions of whiteness and anti-racist pedagogies with their students. Though I felt knowledgeable about racial, ethnic, and cultural impacts in the classroom, I was not prepared for the extent that race impacted participants' experiences. It is possible that my lack of preparedness reinforced racial biases that participants held and did not provide them with the tools necessary to unpack their own relationship with whiteness. It also is possible that I reinscribed whiteness on members of the community with whom we engaged. Thus, it is important for me to continually examine whiteness and my entanglement with it as a White music teacher educator and researcher, so I may better facilitate experiences, specifically for White preservice music teachers in the future. As Talbot (2018) asserted,

If we wish to truly do the work of making music education an inclusive and representative experience "for all," then we must be willing to take a hard look at ourselves individually and question and examine our own participation in structures of power (8-9).

Embedding antiracism and antiracist pedagogies through the diversification of curriculum, the development of coursework dedicated to examining the sociocultural and political contexts of schooling, education and music education, and facilitation of field experiences in a variety of settings is crucial to creating systemic change in preservice music teacher preparation. Music teacher educators need to more frequently center a critical whiteness framework in research and in practice to continue to reveal and name racist policies, curricula, and pedagogies, both in 
school music and in music teacher preparation programs. White music teacher educators also must understand notions of whiteness and critically examine these issues in their own lived experiences and in their music teacher preparation programs. This work is necessary in order to truly work toward anti-racist teaching and racial equity in schools and society.

\section{About the Author}

Andrea VanDeusen is an Assistant Professor of Music Education at East Carolina University, where she teaches foundations and methods courses in music education and conducts the University Chorale. VanDeusen previously taught secondary choral and general music in Michigan, New Jersey, and Switzerland. She holds Bachelor and Master of Music degrees from Western Michigan University and a $\mathrm{Ph}$. D. in music education from Michigan State University. Her research interests include developing preservice music teachers' cultural competence, culturally relevant and sustaining pedagogies, and social justice in music education.

\section{References}

Bonilla-Silva, Eduardo. 2013. Racism without racists: Color-blind racism and the persistence of racial inequality in the United States. New York, NY: Rowman \& Littlefield.

Bradfield-Kreider, Paula. 2001. Personal transformations from inside out: Nurturing monocultural teachers' growth toward multicultural competence. Multicultural Education 8 (4): 31-4.

Bradley, Deborah. 2006. Music education, multiculturalism, and anti-racismCan we talk? Action, Criticism, and Theory for Music Education 5 (2): 1-30.

Bradley, Deborah. 2007. The sounds of silence: Talking race in music education. Action, Criticism, and Theory for Music Education 6 (4): 132-62.

Bradley, Deborah. 2009. Oh, that magic feeling! Multicultural human subjectivity, community and fascism's footprints. Philosophy of Music Education Review 17 (1): $56-74$.

Bradley, Deborah. 2015. Hidden in plain sight: Race and racism in music education. In The Oxford handbook of social justice in music education, edited by Cathy Benedict, Patrick Schmidt, Gary Spruce, and Paul Woodford, 190-203. New York, NY: Oxford University Press.

VanDuesen, Andrea. Revealing whiteness in preservice music teacher education. Action, Criticism, and Theory for Music Education 20 (1): 121-41. https://doi.org/10.22176/act20.1.121 
Cabrera, Nolan L., Jesse. S. Watson, and Jeremy D. Franklin. 2016. Racial arrested development: A critical whiteness analysis of the campus ecology. Journal of Analysis of College Student Development 57 (2): 119-34.

Cockrell, Karen. S., Peggy L. Placier, Dan H. Cockrell, and Julie N. Middleton. 1999. Coming to terms with "diversity" and "multiculturalism" in teacher education: Learning about our students, changing our practice. Teaching and Teacher Education 15: 351-66.

Creswell, John W. 2013. Qualitative inquiry and research design: Choosing among five approaches (3rd ed.). Thousand Oaks, CA: Sage.

Cross, Stephanie Behm, Nermin Tosmur-Bayazit, and Alyssa Hadley Dunn. 2018. Whiteness as a dissonant state: Exploring one White male student teacher's experiences in urban contexts. Journal of Teacher Education 70 (4): 1-13. https://doi.org/10.1177/0022487118774038

Crowley, Ryan M. 2016. Transgressive and negotiated White racial knowledge. International Journal of Qualitative Studies in Education 29 (8): 1016-29. https://doi.org/10.1080/09518398.2016.1174901

del Prado Hill, Pixita, Ellen S. Friedland, and Stephen Phelps. 2012. How teacher candidates' perceptions of urban students are influenced by field experiences: A review of the literature. Action in Teacher Education 34: 77-96.

DiAngelo, Robin. J. 2011. White fragility. International Journal of Critical Pedagogy 3: 54-70.

Elpus, Ken and Carlos R. Abril. 2019. Who enrolls in high school music? A national profile of U.S. students, 2009-2013. Journal of Research in Music Education 67 (3): $323-38$.

Harris, Cheryl. 1993. Whiteness as property. Harvard Law Review 106 (8): 170191.

Harris, Cheryl. 1995. Whiteness as property. In Critical race theory: The key writings that formed the movement, edited by Cornel West, Kimberlé Crenshaw, Neil Gotanda, Gary Peller, and Kendall Thomas, 276-91. New York, NY: The New Press.

Hart, Andrew, and Jane Montague. 2016. Negotiating identity and alterity: Cultural competence, colonization and cultural voyeurism in students' workbased learning. Journal of Psychological Issues and Organizational Culture 6 (3): 7-23.

VanDuesen, Andrea. Revealing whiteness in preservice music teacher education. Action, Criticism, and Theory for Music Education 20 (1): 121-41. https://doi.org/10.22176/act20.1.121 
Hess, Juliet. 2017. Equity and music education: Euphemisms, terminal naivety, and whiteness. Action, Criticism, and Theory for Music Education 16 (3): 1547. https://doi.org/10.22176/act16.3.15

Irvine, Jacqueline Jordan. 2003. Educating teachers for diversity: Seeing with a cultural eye. New York, NY: Teachers College Press.

Kelly, Steven N. 2003. The influence of selected cultural factors on the environmental teaching preference of undergraduate music education majors. Journal of Music Teacher Education 12 (2): 40-44. https://doi.org/ 10.1177/10570837030120020106

Koza, Julia. E. 2008. Listening for whiteness: Hearing racial politics in undergraduate school music. Philosophy of Music Education Review 16 (2): 145-55.

Ladson-Billings, Gloria. 2001. Crossing over to Canaan: The journey of new teachers in diverse classrooms. San Francisco, CA: Jossey-Bass.

Ladson-Billings, Gloria. 2009. The dreamkeepers: Successful teachers of AfricanAmerican children. San Francisco, CA: Jossey-Bass.

Leonardo, Zeus. 2004. The color of supremacy: Beyond the discourse of "white privilege." Education Philosophy and Theory 36 (2): 137-52.

Matias, Cheryl E. 2015. "Why do you make me hate myself?": Re-teaching whiteness, abuse, and love in urban teacher education. Teaching Education 27 (2): 194-211. https://doi.org/10.1080/10476210.2015.1068749

Matias, Cheryl E. 2016. Feeling White: Whiteness, emotionality, and education. Boston, MA: Sense Publishers.

Matias, Cheryl E., Kara M. Viesca, Dorothy F. Garrison-Wade, Madhavi Tandon, and Rene Galindo. 2014. "What is critical whiteness doing in OUR nice field like critical race theory?" Applying CRT and CWS to understand the White imaginations of White teacher candidates. Equity \& Excellence in Education 47 (3): 289-304. https://doi.org/10.1080/10665684.2014.933692

McKoy, Constance L. 2013. Effects of selected demographic variables on music student teachers' self-reported cross-cultural competence. Journal of Research in Music Education 6o (4): 375-94. https://doi.org/10.1177/0022429 412463398

National Center for Education Statistics. 2019. Indicator 7: Racial/ethnic concentration in public schools. https://nces.ed.gov/programs/raceindicators/indicator_RBE.asp

VanDuesen, Andrea. Revealing whiteness in preservice music teacher education. Action, Criticism, and Theory for Music Education 20 (1): 121-41. https://doi.org/10.22176/act20.1.121 
National Center for Education Statistics. 2020. Characteristics of public school teachers. https://nces.ed.gov/programs/coe/indicator_clr.asp

Nishi, Naomi W, Cheryl E. Matias, Roberto Montoya, and Geneva L. Sarcedo. 2016. Whiteness FAQ: Responses and tools for confronting college classroom questions. Journal of Critical Thought and Praxis 5 (1): 1-34.

Picower, Bree. 2009. The unexamined Whiteness of teaching: How White teachers maintain and enact dominant racial ideologies. Race, Ethnicity and Education 12 (2): $197-215$.

Rodriguez, Nelson M. 2000. Projects of whiteness in critical pedagogy. In Dismantling white privilege: Pedagogy, politics, and whiteness, edited by Nelson M. Rodriguez and Leila E. Villaverde, 1-24. New York: P. Lang.

Saldaña, Johnny. 2013. The coding manual for qualitative researchers (2nd ed.). Thousand Oaks, CA: Sage.

Salvador, Karen, and Kristen Allegood. 2014. Access to music education with regard to race in two urban areas. Arts Education Policy Review 115 (3): 82-92. https://doi.org/10.1080/10632913.2014.914389

Salvador, Karen, and Jacqueline Kelly-McHale. 2017. Music teacher educator perspectives on social justice. Journal of Research in Music Education 65 (1): 624.

Sleeter, Christine. 2001. Preparing teachers for culturally diverse schools: Research and the overwhelming presence of Whiteness. Journal of Teacher Education 52 (2): 94-106.

Stake, Robert. E. 1995. The art of case study research. Thousand Oaks, CA: Sage.

Talbot, Brent C. 2018. Marginalized voices in music education. New York, NY: Routledge.

Taylor, Paul C. 1999. Malcolm's conk and Danto's colors: Or, four logical petitions concerning race, beauty, and aesthetics. The Journal of Aesthetics and Art Criticism 57 (1): 16-20.

VanDeusen, Andrea J. 2019. A cultural immersion field experience: Examining preservice music teachers' beliefs about cultural differences in the music classroom. Journal of Music Teacher Education 28 (3): 43-7.

Vaugeois, Lise. 2007. Social justice and music education: Claiming the space of music education as a site of postcolonial contestation. Action, Criticism, and Theory for Music Education 6 (4): 163-200. 
Vaught, Sabina E., and Angelina E. Castagno. 2008. "I don't think I'm a racist": Critical race theory, teacher attitudes, and structural racism. Race, Ethnicity, and Education 11 (2): 95-113. https://doi.org/10.108o/13613320802110217

\section{Note}

${ }^{1}$ Participants are identified by their self-selected pseudonym. 